\title{
Kemampuan Mikrob Endofit dan Rizosfer Tanaman Karet dalam Mengendalikan Rigidoporus lignosus
}

\section{The Ability of Endophytic and Rhizospheric Microbes of Rubber Trees to Control Rigidoporus lignosus}

\author{
Siti Hardiyanti, Bonny Purnomo Wahyu Soekarno*, Titiek Siti Yuliani \\ Institut Pertanian Bogor, Bogor 16680
}

\begin{abstract}
ABSTRAK
Rigidoporus lignosus merupakan patogen penting pada tanaman karet yang mengakibatkan penyakit akar putih. Penggunaan mikrob antagonis merupakan salah satu teknik pengendalian yang direkomendasikan untuk patogen ini. Penelitian ini bertujuan memperoleh agens hayati dari dalam jaringan akar dan rizosfer tanaman karet yang berpotensi mengendalikan $R$. lignosus. Tahapan penelitian terdiri atas isolasi mikrob endofit dan rizosfer dari tanaman karet, uji patogenisitas, seleksi secara in vitro, pengujian secara in vivo, pengujian pelarut fosfat dan pengikat nitrogen, dan identifikasi. Sebanyak 99 isolat bakteri dan 18 isolat cendawan nonpatogen berhasil diisolasi dari akar dan rizosfer tanaman karet. Berdasarkan pengujian in vitro dan in vivo diperoleh 2 isolat bakteri dan 3 isolat cendawan yang mampu menghambat pertumbuhan R. lignosus, yaitu bakteri endofit ME8, bakteri rizosfer MR3, cendawan endofit CB8, CB6, dan CL3. Bakteri endofit ME8 mampu melarutkan fosfat dan memfiksasi nitrogen. Bakteri rizosfer MR3 hanya mampu memfiksasi nitrogen. Berdasarkan karakter morfologinya, isolat CB8 teridentifikasi sebagai hifa steril, CB6 sebagai Chaetomium sp., dan CL3 sebagai Penicillium sp. Berdasarkan perunutan gen 16S rRNA, bakteri ME8 memiliki kekerabatan dengan Bacillus siamensis B268, dan bakteri MR3 memiliki kekerabatan dengan B. amylolyquifaciens SXAU001. Mikrob endofit dan rizosfer yang telah diisolasi dari tanaman karet memiliki potensi sebagai agens hayati untuk mengendalikan $R$. lignosus.
\end{abstract}

Kata kunci: fiksasi nitrogen, mikrob antagonis, pelarut fosfat, penyakit akar putih

\section{ABSTRACT}

Rigidoporus lignosus is the most important pathogen of rubber tree which causes white root rot disease. The use of antagonistic microbe is recommended to control this pathogen. This research was conducted to isolate endophytic and rhizospheric microbes, and to study their ability to inhibit growth of $R$. lignosus. Research consisted of isolation of endophytic and rhizospheric microbes, pathogenicity test, in vitro and in vivo assays, growth promotion assays, and identification. There were 99 isolates of bacteria and 18 isolates of fungi isolated from the root and rhizosphere of rubber trees. In vitro and in vivo assay showed that 2 bacterial isolates, i.e. endophytic bacteria ME8, and rhizospheric bacteria MR3; and 3 fungal isolates, i.e. endophytic fungi CB8, CB6, and CL3 were able to inhibit the growth of $R$. lignosus. Endophytic bacteria ME8 showed the ability of solibilizing phosphate and fixing nitrogen. Rhizospheric bacteria MR3 showed the ability of solubilizing phosphate. The isolates CB6 and CL3 were very similar with Chaetomium sp. and Penicillium sp., respectively based on morphological characters; while CB8 was identified as mycelial sterile. Based on 16S rRNA sequences, endophytic bacterium ME8 and rhizospheric bacteria ME3 were identified as Bacillus siamensis B268 and B.

*Alamat penulis korespondensi: Departemen Proteksi Tanaman, Fakultas Pertanian, Institut Pertanian Bogor, Jalan Kamper, Kampus IPB Darmaga, Bogor 16680

Tel: 0251-8629364, Faks: 0251-8629362; surel: bonnypws@gmail.com 
amylolyquefaciens BCRh10, respectively. Endophytic and rhizospheric microbes isolated from rubber trees has the potency as biocontrol agents of $R$. lignosus.

Key words: antagonistic microbe, nitrogen fixer, phosphate solubilizer, root rot disease

\section{PENDAHULUAN}

Karet(Heveabrasiliensis) merupakan salah satu komoditas perkebunan yang memegang peranan penting bagi perekonomian Indonesia. Penyakit akar putih yang disebabkan oleh Rigidoporus lignosus merupakan salah satu faktor pembatas dalam budi daya tanaman karet. Kehilangan hasil yang disebabkan penyakit akar putih lebih besar dibandingkan dengan penyakit lain atau hama di berbagai negara penghasil karet. Pada tahun 2015 luas serangan $R$. lignosus di Indonesia mencapai 26 ribu ha dan menyebabkan kerugian hasil sebesar Rp75.67 miliar (Isnaini 2016).

Tanaman yang terinfeksi $R$. lignosus menunjukkan gejala daun menguning, daun gugur, pangkal batang membusuk dan mengakibatkan pohon mudah tumbang. Pada stadium lanjut penyakit ini menyebabkan kematian tanaman sehingga produktivitas kebun menurun. Rizomorf dari sumber infeksi akan menyebar melalui tanah dan menginfeksi tanaman sehat. Selain itu tubuh buah (basidiokarp) pada bagian pangkal batang tanaman juga dapat menyebarkan basidiosporanya (Omo-Ikerodah 2012).

Pengendalian penyakit akar putih yang telah dilakukan ialah penggunaan fungisida sintetis, kultur teknis, mekanis, sanitasi, dan pengendalian hayati. Pengendalian hayati dengan pemanfaatan agens antagonis merupakan alternatif yang saat ini banyak diteliti dan digunakan karena dinilai lebih efektif dan ramah lingkungan. Agens antagonis yang telah dimanfaatkan dalam mengendalikan $R$. lignosus sebagian besar adalah Trichoderma harzianum dan $T$. koningii (Jayasuriya dan Thennakoon 2007). Selain memiliki sifat sebagai agens biokontrol, banyak agens antagonis dapat memacu pertumbuhan tanaman karena mampu memproduksi hormon pertumbuhan, memfiksasi nitrogen, melarutkan fosfat, dan memproduksi siderofor. Penelitian ini bertujuan mendapatkan agens hayati dari dalam jaringan akar dan rizosfer tanaman karet yang berpotensi mengendalikan $R$. lignosus.

\section{BAHAN DAN METODE}

\section{Isolasi Mikrob dari Jaringan Akar Tanaman}

Akar tanaman karet diperoleh dari perkebunan karet rakyat di Kabupaten Muaro Jambi dan Kabupaten Sarolangun, Provinsi Jambi. Sampel akar dicuci menggunakan air mengalir dan dipotong ukuran 1-2 cm. Sebanyak $1 \mathrm{~g}$ akar disterilkan permukaannya dengan merendam dalam alkohol 70\% selama 1 menit dan dilanjutkan dengan merendam pada $\mathrm{NaOCl} 2.5 \%$ selama 2 menit, kemudian dibilas menggunakan akuades steril sebanyak 3 kali. Keberhasilan sterilisasi diuji dengan menggoreskan akar pada medium trypticase soya agar (TSA) $10 \%$.

Isolasi bakteri dilakukan dengan menghaluskan akar tersebut dan menambahkan $9 \mathrm{~mL}$ akuades steril, kemudian diencerkan secara berseri hingga $10^{-6}$. Sebanyak $0.1 \mathrm{~mL}$ suspensi disebar pada medium TSA $10 \%$ dan diinkubasi selama 2 hari. Isolasi cendawan dilakukan dengan meletakkan potongan akar yang telah disterilisasi permukaannya pada medium agar-agar dekstrosa kentang (ADK). Cawan diinkubasi selama 7 hari untuk memperoleh cendawan. Koloni yang menunjukkan morfologi berbeda masingmasing diremajakan pada medium ADK untuk mendapatkan biakan murni.

\section{Isolasi Mikrob dari Rizosfer Tanaman Karet}

Isolasi mikrob dari rizosfer tanaman karet dilakukan dengan metode pengenceran berseri. Sebanyak $1 \mathrm{~g}$ tanah ditambahkan akuades steril hingga $10 \mathrm{~mL}$. Suspensi lalu digoyang pada kecepatan 100 rpm selama 
15 menit, kemudian diencerkan secara berseri hingga $10^{-6}$. Isolasi cendawan dilakukan dengan mengulturkan $0.1 \mathrm{~mL}$ suspensi tanah pada medium ADK dan diinkubasi selama 7 hari, sedangkan bakteri pada medium TSA $10 \%$ dan diinkubasi selama 2 hari. Isolat cendawan dan bakteri dengan morfologi berbeda dimurnikan.

\section{Penyiapan Cendawan Patogen}

$R$. lignosus diperoleh dari Balai Penelitian Karet Sembawa, Sumatra Selatan. Galur cendawan ini diremajakan selama 7 hari pada medium ADK untuk digunakan pada uji lanjut.

\section{Uji Patogenisitas}

Uji patogenisitas bakteri dilakukan dengan pengujian respons hipersensitif pada tanaman tembakau. Galur bakteri ditumbuhkan pada medium trypticase soya broth (TSB) dan digoyang selama 24 jam dengan kecepatan $100 \mathrm{rpm}$. Sebanyak $1 \mathrm{~mL}\left(10^{8} \mathrm{cfu} \mathrm{mL}^{-1}\right)$ suspensi bakteri diinfiltrasikan pada bagian bawah daun tembakau dan diinkubasi selama 48 jam. Galur bersifat patogen pada tanaman apabila terjadi nekrotik pada daun tembakau.

Uji patogenisitas cendawan dilakukan dengan mengamati gejala pada benih padi karena dapat menimbulkan gejala yang lebih cepat. Benih padi disterilkan permukaannya dengan merendam benih dalam larutan $\mathrm{NaOCl} 2 \%$ selama 2 menit, kemudian dibilas dengan akuades steril sebanyak 3 kali. Benih ditumbuhkan pada galur cendawan yang telah berumur 7 hari pada medium ADK. Pengamatan dilakukan setelah 14 hari dengan melihat gejala pada benih. Apabila terjadi nekrotik atau benih tidak tumbuh sempurna maka galur tersebut bersifat patogen pada tanaman.

\section{Uji Antibiosis}

Uji antibiosis dilakukan untuk menentukan kemampuan mikrob dalam menekan pertumbuhan $R$. lignosus. Pengujian menggunakan metode biakan ganda, yaitu galur bakteri digoreskan pada bagian tengah cawan petri kemudian pada sisi kanan dan kiri bakteri diinokulasi $R$. lignosus dengan jarak $2.5 \mathrm{~cm}$.
Galur cendawan endofit dan rizosfer diinokulasikan pada cawan petri berisi medium ADK dan pada jarak $2.5 \mathrm{~cm}$ dari cendawan $R$. lignosus. Zona bening yang terbentuk di antara kedua isolat menunjukkan kemampuan mikrob dalam menghasilkan senyawa antibiosis. Persentase hambatan diukur pada 7 hari setelah inokulasi menggunakan rumus:

Persentase hambatan $=\frac{\mathrm{R} 1-\mathrm{R} 2}{\mathrm{R} 1} \times 100 \%$, dengan $\mathrm{R} 1$, jari-jari koloni $R$. lignosus yang tumbuh menjauhi mikrob yang diuji; R2, jari-jari koloni $R$. lignosus yang mendekati mikrob yang diuji.

\section{Uji Hiperparasitisme}

Uji hiperparasitisme dilakukan terhadap 3 galur cendawan terbaik pada uji antibiosis. Pengujian dilakukan dengan mengamati pertemuan antara kedua koloni pada uji biakan ganda menggunakan mikroskop. Indikator aktivitas hiperparasitisme dilihat dari adanya pelilitan pada hifa $R$. lignosus.

\section{Uji Produksi Senyawa Volatil}

Pengujian dilakukan terhadap 3 galur terbaik pada uji antibiosis. Pengujian dilakukan menggunakan dua cawan petri berukuran sama. Isolat cendawan antagonis dikulturkan pada medium ADK, sedangkan bakteri antagonis dikulturkan pada medium TSA, kemudian biakan tersebut ditutup dengan cawan petri yang telah ditumbuhkan $R$. lignosus. Setelah 7 hari, diameter $R$. lignosus diukur dan persentase penghambatan dihitung menggunakan rumus:

$$
\% \text { penghambatan }=\frac{\phi \mathrm{K}-\phi \mathrm{P}}{\phi \mathrm{K}} \times 100 \% \text {, dengan }
$$

$\phi \mathrm{K}$, diameter $R$. lignosus pada perlakuan kontrol; $\phi \mathrm{P}$, diameter $R$. lignosus pada perlakuan mikrob antagonis.

\section{Uji Antagonisme terhadap $R$. lignosus secara in Vivo}

Seleksi in vivo dilakukan menggunakan potongan akar tanaman karet mengikuti protokol pada Jayasuriya dan Thenaakoon (2007) yang telah dimodifikasi. Akar yang digunakan berasal dari tanaman Klon GT umur 3 tahun dari kebun percobaan Pusat 
Penelitian Bioteknologi dan Bioindustri Indonesia di Ciampea. Galur mikrob antagonis yang digunakan ialah isolat yang memiliki daya hambat lebih dari 50\% pada seleksi in vitro. Pengujian dilakukan dengan menggunakan kotak plastik dan diisi dengan tanah steril hingga $1 / 2$ bagian. Potongan akar karet (panjang 8-10 cm, lebar 2-3 cm) disterilkan menggunakan penangas air pada suhu $50{ }^{\circ} \mathrm{C}$ selama 15 menit, kemudian direndam dalam suspensi agens antagonis $\left(10^{8} \mathrm{cfu} \mathrm{mL}^{-1}\right)$ selama 6 jam. Sebagai kontrol, akar direndam dalam akuades steril. Akar tanaman yang telah diberi perlakukan diletakkan di atas permukaan tanah. Sisa agens antagonis disiramkan di atas permukaan akar. Inokulasi cendawan $R$. lignosus dilakukan pada jarak $1 \mathrm{~cm}$ dari ujung akar pada waktu yang sama. Setelah diinkubasi selama 10 hari pertumbuhan miselium dan persentase penghambatannya dihitung.

Karakterisasi Bakteri Antagonis sebagai Pelarut Fosfat dan Penambat Nitrogen

Uji Pelarut Fosfat. Bakteri antagonis dikulturkan di atas kertas cakram pada medium Pikovskaya's agar lalu diinkubasi pada suhu ambien selama 7 hari. Kemampuan bakteri dalam menambat fosfat ditunjukkan dengan terbentuknya zona bening di sekitar koloni bakteri.

Uji Penambat Nitrogen. Bakteri antagonis dikulturkan pada medium semi padat nitrogen free malat dan diinkubasi selama 48 jam. Apabila terdapat lapisan lendir maka isolat bakteri uji tersebut memiliki kemampuan dalam penambat nitrogen.

\section{Identifikasi Agens Antagonis}

Cendawan antagonis diidentifikasi berdasarkan karakter morfologi menurut Watanabe (2002) dan Barnet dan Hunter(2006). Bakteri antagonis diidentifikasi menggunakan teknik polymerase chain reaction (PCR) dengan primer universal, yaitu forward primer 27F (5'-AGAGTTTGATCCTGGCTCAG-3') dan reverse primer 1429R (5'-GGTTACC TTGTTACGACTT-3') (Islam et al. 2012).
Proses amplifikasi yang dilakukan sebanyak 30 siklus pada kondisi pra PCR suhu $95^{\circ} \mathrm{C}$ selama 5 menit, denaturasi suhu $95{ }^{\circ} \mathrm{C}$ selama 1 menit, aneling suhu $55^{\circ} \mathrm{C}$ selama 5 menit, elongasi suhu $72{ }^{\circ} \mathrm{C}$ selama 1.5 menit, dan post-PCR pada suhu $72{ }^{\circ} \mathrm{C}$ selama 5 menit. Hasil amplifikasi DNA selanjutnya dirunutkan di laboratorium First Base, Malaysia. Data hasil perunutan dicocokkan dengan data GenBank National Center for Biotechnology Information (NCBI) menggunakan BLAST pada http://www.ncbi.nlm.nih.org.

\section{Analisis Data}

Pengujian antibiosis, uji produksi senyawa volatil, dan pengujian secara in vivo disusun dalam rancangan acak lengkap. Masingmasing percobaan diulang 3 kali dengan menggunakan kontrol negatif. Isolat dengan persentase hambatan tertinggi pada uji antibiosis merupakan kandidat isolat unggul yang digunakan dalam seleksi selanjutnya. Pertumbuhan miselium pada pengujian in vivo dianalisis menggunakan ANOVA dengan program SAS versi 9.1. Perlakuan yang berpengaruh nyata diuji lanjut dengan duncan multiple range test pada taraf $\alpha 5 \%$.

\section{HASIL}

\section{Mikrob dari Jaringan Tanaman dan Rizosfer Tanaman Karet}

Pada penelitian ini diperoleh 131 isolat bakteri dan 28 isolat cendawan yang terdiri atas 55 isolat bakteri dari jaringan tanaman, 76 isolat bakteri rizosfer, 15 isolat cendawan jaringan tanaman dan 13 isolat cendawan dari rizosfer. Berdasarkan pengujian patogenisitas sebanyak 99 isolat bakteri dan 18 isolat cendawan bersifat nonpatogen (Tabel 1).

\section{Potensi Bakteri Antagonis dalam Menghambat Pertumbuhan R. lignosus}

Hasil uji biakan ganda terhadap 99 isolat bakteri menunjukkan 2 isolat bakteri mampu menghambat pertumbuhan $R$. lignosus lebih dari 50\%, yaitu bakteri endofit ME8 dan bakteri rizosfer MR3 (Gambar 1). Keduanya 
Tabel 1 Jumlah mikrob yang diisolasi dari jaringan akar dan rizosfer tanaman karet

\begin{tabular}{lcccccc}
\hline \multirow{2}{*}{ Asal mikrob } & \multicolumn{2}{c}{ Mikrob total } & & \multicolumn{2}{c}{ Mikrob nonpatogenik } \\
\cline { 2 - 3 } \cline { 6 - 7 } & Bakteri & Cendawan & & Bakteri & Cendawan \\
\hline Jaringan Akar & 55 & 15 & & 42 & 10 \\
Rizosfer & 76 & 13 & & 57 & 8 \\
\hline Total & 131 & 28 & & 99 & 18 \\
\hline
\end{tabular}

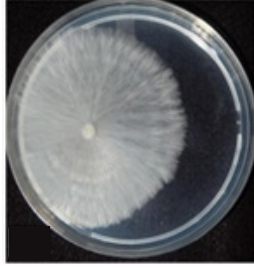

a

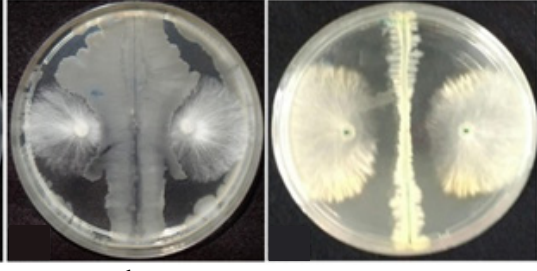

b c

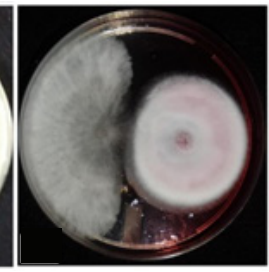

$\mathrm{d}$

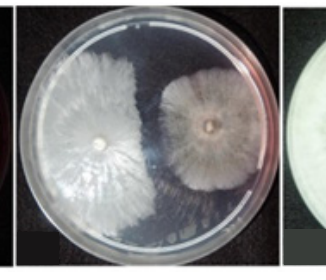

e

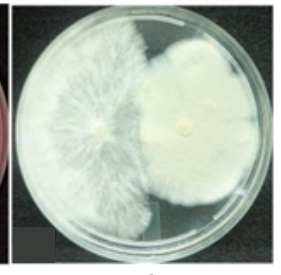

f

Gambar 1 Penghambatan pertumbuhan koloni Rigidoporus lignosus oleh mikrob antagonis. a, kontrol; b, bakteri endofit ME8; c, bakteri rizosfer MR3; d, cendawan endofit hifa steril CB8; e, cendawan endofit CB6; dan f, cendawan endofit CL3.

menghambat pertumbuhan miselium $R$. lignosus masing-masing hingga $100 \%$ secara in vivo pada akar tanaman karet (Tabel 2).

\section{Potensi Cendawan Antagonis dalam Menghambat Pertumbuhan R. lignosus}

Berdasarkan uji biakan ganda diperoleh 3 cendawan endofit yang memiliki daya hambat tinggi, yaitu galur CB8, CB6, dan CL3. Ketiganya mampu menghambat pertumbuhan miselium lebih dari $50 \%$ pada pengujian in vivo. Pengujian produksi senyawa volatil menunjukkan bahwa hanya cendawan CB8 yang mampu menghambat pertumbuhan $R$. lignosus (Tabel 3). Cendawan CL3 dan CB8 memiliki aktivitas hiperparasitisme ditunjukkan dengan adanya pelilitan pada hifa $R$. lignosus, sementara cendawan CB6 menyebabkan ukuran hifa $R$. lignosus mengecil (Gambar 2).

\section{Potensi Bakteri Antagonis sebagai Agens Pemacu Pertumbuhan}

Bakteri ME8 mampu menambat fosfat yang ditandai oleh terbentuknya zona bening di sekitar koloni setelah 7 hari inkubasi. Hasil pengujian lainnya juga menunjukkan bakteri ME8 dan MR3 termasuk kelompok bakteri penambat nitrogen yang ditandai oleh terbentuknya lapisan lendir dan pelikel (Tabel 4).

\section{Identifikasi Cendawan dan Bakteri Antagonis}

Berdasarkan karaketristik morfologi, cendawan CB8 merupakan hifa steril, CB6 diidentifikasi sebagai Chaetomium sp., danCL3 sebagai Penicillium sp. Berdasarkan perunutan gen 16S rRNA, isolat bakteri ME8 memiliki kekerabatan yang dekat dengan Bacillus siamensis B268 (no aksesi: KU644287), dan bakteri MR3 memiliki kekerabatan yang dekat dengan B. amylolyquifaciens SXAU001 (no aksesi: KY271752).

\section{PEMBAHASAN}

Mikrob antagonis yang telah diisolasi dari jaringan akar dan rizosfer tanaman karet memiliki potensi untuk dikembangkan sebagai agens hayati dalam mengendalikan $R$. lignosus. Hasil pengujian secara in vitro diperoleh isolat-isolat potensial yang memiliki beberapa mekanisme pengendalian patogen. Mekanisme bakteri antagonis meliputi kompetisi ruang dan nutrisi, memproduksi senyawa allelokimia, dan menginduksi ketahanan sistemik (ISR) tanaman inang (Compant et al. 2005). Suatu agens antagonis dapat memiliki 1 atau lebih mekanisme dalam mengendalikan patogen.

Isolat bakteri ME8 dan MR3 merupakan isolat bakteri antagonis yang potensial 
Tabel 2 Potensi bakteri antagonis dalam menghambat pertumbuhan Rigidoporus lignosus

\begin{tabular}{lcccc}
\hline & Uji in vitro & \multicolumn{2}{c}{ Uji in vivo } \\
\cline { 2 - 3 } Isolat & $\begin{array}{c}\text { Daya hambat } \\
(\%)\end{array}$ & & $\begin{array}{c}\text { Pertumbuhan miselium } \\
(\mathrm{cm})\end{array}$ & $\begin{array}{c}\text { Daya hambat } \\
(\%)\end{array}$ \\
\hline ME8 & 70.0 & $0.0 \mathrm{~b}$ & 100 \\
MR3 & 62.5 & $0.0 \mathrm{~b}$ & 100 \\
Kontrol & 0.0 & $10.0 \mathrm{a}$ & 0.0 \\
\hline
\end{tabular}

Angka yang diikuti huruf yang sama dalam kolom yang sama tidak berbeda nyata pada uji Duncan pada $\alpha 5 \%$

Tabel 3 Potensi cendawan antagonis dalam menghambat pertumbuhan Rigidoporus lignosus

\begin{tabular}{|c|c|c|c|c|c|}
\hline \multicolumn{2}{|c|}{ Isolat cendawan antagonis } & \multicolumn{2}{|c|}{$\begin{array}{c}\text { Uji in vitro } \\
\text { Daya hambat (\%) } \\
\end{array}$} & \multicolumn{2}{|c|}{ Uji in vivo } \\
\hline Isolat & Genus & Antibiosis & $\mathrm{VOC}^{\mathrm{a}}$ & $\begin{array}{l}\text { Pertumbuhan miselium } \\
(\mathrm{cm})^{\mathrm{b}}\end{array}$ & $\begin{array}{c}\text { Daya hambat } \\
(\%)\end{array}$ \\
\hline CB8 & Hifa steril CB8 & 65.3 & 13.0 & $1.2 \mathrm{bc}$ & 74.2 \\
\hline CB6 & Chaetomium sp. & 57.8 & 0.0 & $2.7 \mathrm{~b}$ & 55.5 \\
\hline CL3 & Penicillium sp. & 57.3 & 0.0 & $0.0 \mathrm{c}$ & 100 \\
\hline Kontrol & - & 0.0 & 0.0 & $5.3 \mathrm{a}$ & 0.0 \\
\hline
\end{tabular}

${ }^{a}$, Volatile organic compound

b, Angka yang diikuti huruf yang sama dalam kolom yang sama tidak berbeda nyata pada uji Duncan pada $\alpha 5 \%$

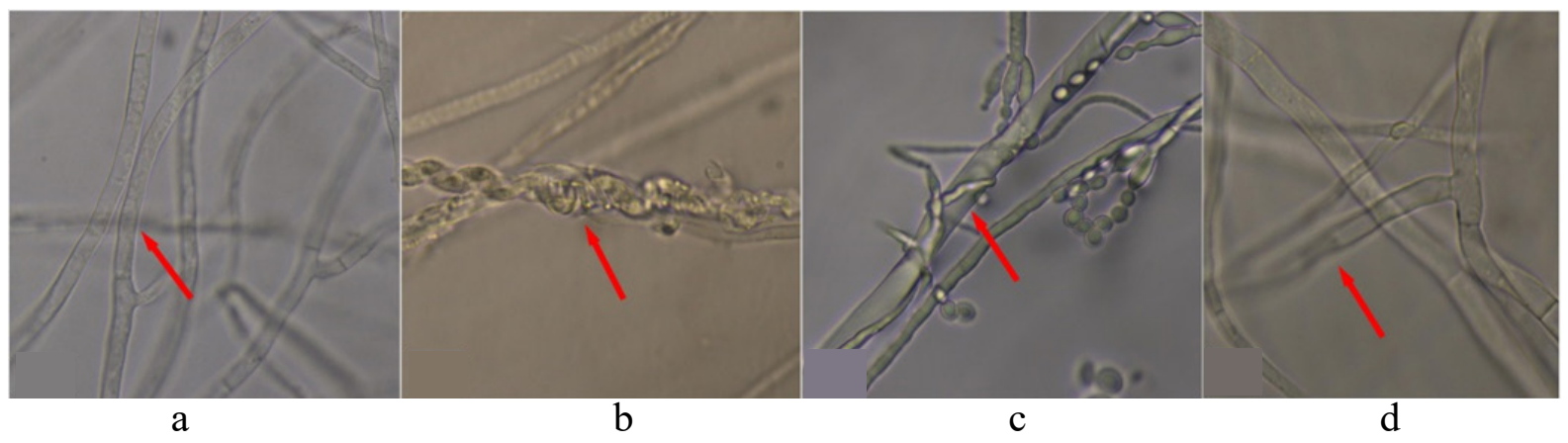

Gambar 2 Aktifitas hiperparasitisme cendawan antagonis pada miselium Rigidoporus lignosus. a, Hifa normal $R$. lignosus; b, pelilitan pada hifa $R$. lignosus oleh cendawan CB8; c, pelilitan pada hifa $R$. lignosus oleh cendawan CL3 dan; d, ukuran hifa $R$ lignosus mengecil akibat parasitisme cendawan CB6.

Tabel 4 Bakteri antagonis sebagai agens pelarut fosfat dan penambat nitrogen

\begin{tabular}{lcc}
\hline Isolat & Pelarut fosfat $(\mathrm{mm})$ & Penambat nitrogen \\
\hline ME8 & 1.4 & + \\
MR3 & 0 & + \\
\hline
\end{tabular}

+ , terdapat lapisan lendir

untuk pengendalian hayati $R$. lignosus pada pengujian in vitro. Bakteri endofit ME8 memiliki pertumbuhan yang cepat dan menghambat pertumbuhan patogen, sedangkan bakteri rizosfer MR3 menghasilkan senyawa antibiosis. Isolat bakteri ME8 dan MR3 juga diketahui mampu mempertahankan potensinya untuk mengendalikan $R$. lignosus dalam kondisi in vivo. Pengendalian $R$. lignosus menggunakan bakteri antagonis selama ini belum banyak diteliti di lapangan. Hasil penelitian Muharni dan Widjajanti (2011) menunjukkan bahwa bakteri Bacillus sp. dan B. apiarus yang diisolasi dari rizosfer tanaman karet bersifat antagonis dengan menghasilkan enzim kitinolitik dan mampu 
menghambat pertumbuhan $R$. lignosus sebesar $6.12 \mathrm{~mm}$ pada pengujian in vitro. Bakteri $B$. amyloliquefaciens diketahui menghasilkan senyawa surfactin, iturin, bacilomycine, azalomycin, acivicin, arthrobactin, rhodutorola acid, valinomycin, stenothricin, enterochelin, dan nocardamin (Wulff et al. 2002).

Kemampuan bakteri dalam melarutkan fosfat dan memfiksasi nitrogen akan memengaruhi kebugaran tanaman inang sehingga lebih toleran terhadap penyakit. Singh et al. (2010) menyatakan bahwa aplikasi bakteri pelarut fosfat memiliki korelasi positif terhadap performa tanaman dengan meningkatkan pertumbuhan dan meningkatkan hasil panen tanaman kedelai sebesar $23.88 \%$. Inokulasi bakteri fiksasi nitrogen pada tanaman tomat dan cabai merah diketahui mampu meningkatkan klorofil tanaman, hara makro dan mikro tanaman, vigor, dan biomassa tanaman (Islam et al. 2012).

Selain bakteri antagonis diperoleh juga cendawan dari jaringan akar yang mampu menghambat pertumbuhan $R$. lignosus, yaitu cendawan endofit hifa steril CB8, cendawan endofit CB6, dan cendawan endofit CL3. Soytong et al. (2001) menyatakan bahwa Chaetomium globosum menghasilkan senyawa chaetoglobosin dan chaetoviridins yang berperan dalam menekan pertumbuhan patogen.

Cendawan endofit CL3 dan hifa steril CB8 memiliki aktivitas hiperparasitisme dan mengakibatkan hifa $R$. lignosus menjadi lisis, keriput, dan membengkak. Interaksi hiperparasitisme cendawan antagonis Pythium radiosum terhadap Botrytis cinerea menyebabkan koagulasi protoplasma, hifa menjadi kosong, dan kerusakan hifa ini dapat menyebabkan percabangan dan produksi struktur seksual (Paul 1999). Selain bersifat antibiosis, cendawan hifa steril CB8 juga menghasilkan senyawa volatil. Cendawan endofit dapat memproduksi asam volatil seperti alkohol, ester, keton, dan lipid yang mampu menghambat Fusarium solani, Pythium ultimun, dan Rhizoctonia solani (Strobel 2001).
Cendawan antagonis yang telah dimanfaatkan dalam mengendalikan $R$. lignosus sebagian besar merupakan genus Trichodema. Aplikasi T. harzianum pada potongan akar yang terinfeksi $R$. lignosus mengakibatkan pemulihan akar hingga $72 \%$ jika akar terinfeksi ringan, sementara jika terinfeksi berat hanya dapat memulihkan kondisi akar sebesar 23.6\% (Jayasuriya dan Thenaakkon 2007). Hypocrea atroviridis yang diisolasi dari perkebunan karet di Sumatra dapat menghambat pertumbuhan patogen sebesar $77.93 \%$ pada 7 hari setelah inokulasi (Amaria et al. 2015). C. cupreum yang diformulasikan dalam bentuk tepung dan minyak mampu mengurangi insidensi penyakit akar putih pada karet sebesar $60-80 \%$ (Soytong dan Kaewchai 2014).

Hasil penelitian ini membuktikan bahwa bakteri endofit ME8, bakteri rizosfer MR3, cendawan endofit CB8, cendawan endofit CB6, dan cendawan endofit CL3 yang diisolasi dari jaringan akar dan rizosfer tanaman karet memiliki potensi sebagai agens hayati untuk mengendalikan penyakit akar putih.

\section{DAFTAR PUSTAKA}

Amaria W, Harni R, Samsudin. 2015. Evaluasi jamur antagonis dalam menghambat pertumbuhan Rigidoporus microporus penyebab penyakit jamur akar putih pada tanaman karet. JTIDP. 2(1):51-60.

Barnet HL, Hunter BB. 2006. Illustrated Genera of Imperfect Fungi. Ed ke-4. Amerika (US): APS Press.

Compant S, Duffy B, Nowak J, Clement C, Barkal EA. 2005. Use of plant growthpromoting bacteria for biocontrol of plant disease: principle, mechanisms of action, and future prospects. Appl Environ Microbiol. 71:4951-4959. DOI: https://doi.org/10.1128/AEM.71.9.49514959.2005.

Islam MR, Sultana T, Joe MM, Yim W, Cho JC, Sa T. 2012. Nitrogen-fixing bacteria with multiple plant growth-promoting activities enhance growth of tomato and red pepper. 
J Bas Microbiol. 53(1004):1-25. DOI: https://doi.org/10.1002/jobm.201200141.

Isnaini N. 2016. Pengendalian JAP pada Tanaman Karet di Indonesia dengan Dana APBN-TP 2016. www.ditjenbun. pertanian.go.id. [diakses 5 Oktober 2016].

Jayasuriya KE, Thenaakoon BI. 2007. Biological control of Rigidoporus lignosus the cause of white root disease in rubber. $J$ Bio Sci. 36(1):9-16.

Muharni, Widjajanti H. 2011. Skrining bakteri kitinolitik antagonis terhadap pertumbuhan jamur akar putih (Rigidoporus lignosus) dari rizosfir tanaman karet. J Penel Sains. 14(1):14112-14151.

Omo-Ikerodah EE, Omorusi VI, Mokwunye MUB. 2012. Challenges and progress in the control of white root rot disease of Hevea brasiliensis in Africa. World Rural Observ. 4(1):1-2.

Paul B. 1999. Suppression of Botrytis cinera causing the grey mould disease of grape-vine by an aggressive mycoparasite, Phytium radiosum. FEMS Microbiol. 176:25-30. DOI: https://doi. org/10.1111/j.1574-6968.1999.tb13637.x.

Singh AV, Shah S, Prasad B. 2010. Effect of phosphate solubilizing bacteria on plant growth promotion and nodulation in soybeab (Glycine max (L.) Merr.). J Hill Agric. 1(1):35-39.
Soytong K, Kaewchai S. 2014. Biological control of white root of rubber trees using Chaetomium cupreum. J Agric Tech. 10(1):93-103.

Soytong K, Kanokmedhakul S, Kukongviriapa $\mathrm{V}$, Isobe M. 2001. Application of Chaetomium spesies (Ketomuim ${ }^{\circledR}$ ) as a new broad spectrum biological fungicide for plant disease control: Fungal Divers 7: $1-15$.

Strobel GA, Dirkse E, Sears J, Markworth C. 2001. Volatile antimicrobials from Muscodor albus a novel endophytic fungus. Microbiology. 147:2943-2950. DOI: https://doi.org/10.1099/00221287147-11-2943.

Watanabe T. 2002. Pictorial Atlas of Soil and Seed Fungi. Ed ke-2. Washington (US): CRC Pr. DOI: https://doi. org/10.1201/9781420040821.

Wulff EG, Mguni CM, Mansfeld-Giese K, Fels J, Lubeck M, Hockenhull J. 2002. Biochemical and molecular characterization of Bacillus amyloliquefaciens, $B$. subtilis and B. pumilus isolates with distinct antagonistic potential against Xanthomonas campestris pv. campestris. Plant Pathol. 5:574-584. DOI: https://doi. org/10.1046/j.1365-3059.2002.00753.x. 